\title{
Heterosis Studies for Various Morphological Traits of Rice under Drought Conditions
}

\author{
Santosh Kumar*, N.K. Singh, Rajesh Kumar, Satish Kumar Singh, \\ Nilanjaya, Chandan Kumar and Avinash Kumar
}
Department of Plant Breeding and Genetics, Dr. Rajendra Prasad Central Agriculture University Pusa Samastipur- 848125, Bihar, India
*Corresponding author

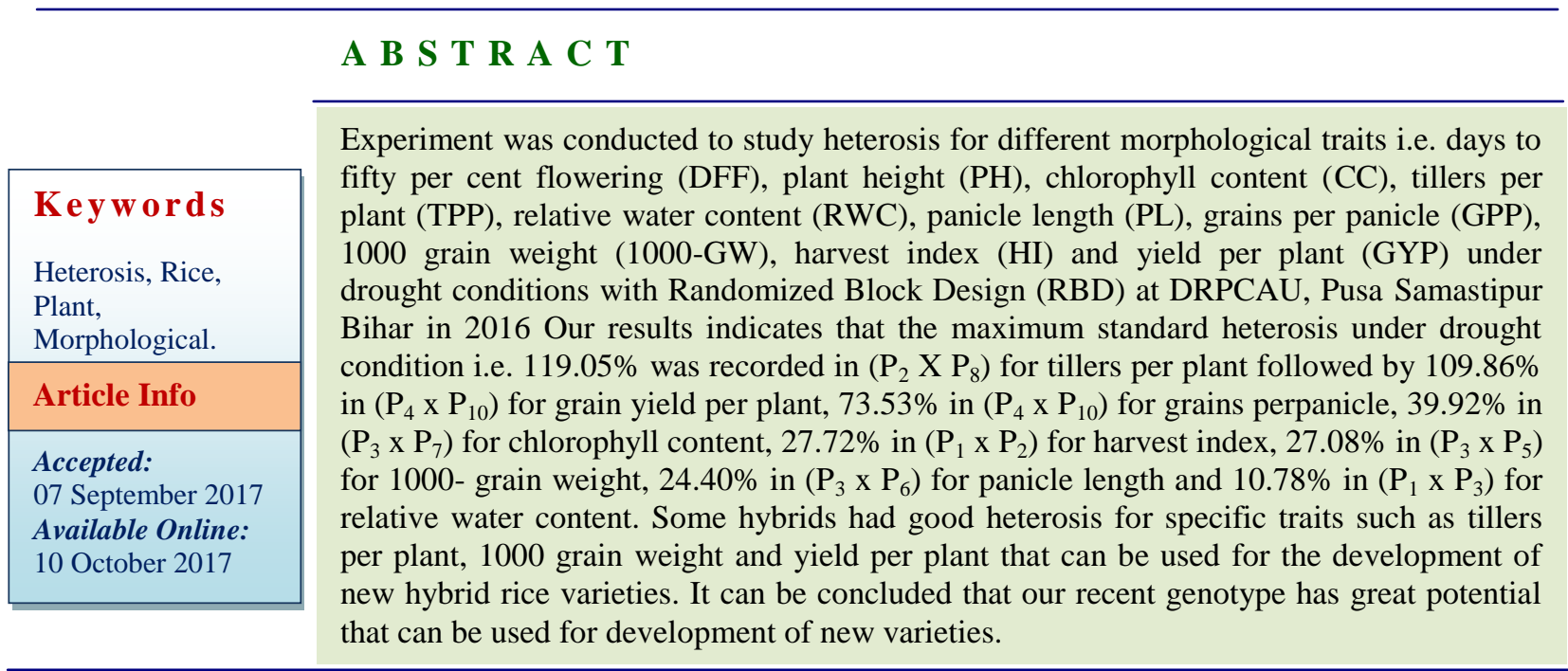

\section{Introduction}

Rice (Oryza sativa L.) is a principal staple food for more than $50 \%$ of the world's population. Rice is grown under diverse ecogeographical conditions in various tropical and subtropical countries, including India and Pakistan. To meet the future food demand, anticipated from the projected world population increase, there is an urgent need to take necessary steps for enhancing the productivity of this crop (Ram et al., 2007). Heterosis breeding is a fundamental tool for the expression of various cross combinations and its potential for commercial exploitation of heterosis under different environmental conditions. Overall positive heterosis desired for yield and yield relating traits and negative heterosis for days to $50 \%$ flowering and plant height (Nuruzzaman et al., 2002). Generally heterosis is expressed in three ways according to the performance of the hybrids over its parents (mid parent and better parent heterosis) and commercially growing rice varieties (standard heterosis) in comparison with different morphological traits (Gupta, 2000). Heterosis breeding is very important genetic tool in conventional breeding for the enhancement of yield and many other yield related traits both qualitative and quantitative in all crops under stress conditions (Srivstava, 2000). Conventional breeding strategy play a 
very important role for the screening, production of high yielding hybrids and exploitation of heterosis as well as the specific combining ability of crosses. The most important point for the plant breeders is to produce high yielding hybrids is the selection of the parents and their hybrids. Diallel analysis is the most powerful tool for estimating the general combining ability (GCA), specific combining ability (SCA) and the exploitation of the heterosis. Positive heterosis for grain yield per plant and other parameters were reported by many researchers (Li et al., 2002). On the other hand, positive significant heterosis was reported by (Hong et al., (2002) and Alam et al., (2004) for yield and various yield contributing traits. Hybrid rice varieties have been released from different countries with greater yield potential 15 to $20 \%$ than the commercial growing rice varieties under different environments (Yuan et al., 2000). Manickavelu et al., (2006) conducted an experiment to develop and evaluate biparental progenies for drought tolerance in rice.

Genetic analysis of biparental progenies resulted that, the traits viz,. days to $50 \%$ RWC and plant height were governed by additive gene action for improvement of these traits while, days to flowering, productive tillers per plant, 1000- grain weight, and grain yield can be improved by heterosis breeding. Main objective of the study was to evaluate rice genotypes for yield and yield related traits for heterosis to develop new breeding lines that can perform better in water stress conditions.

\section{Materials and Methods}

The experimental materials for the present study consist of 10 rice genotypes received from Department of Plant Breeding and Genetics, Dr. Rajendra Prasad Central Agricultural University, Pusa, Samastipur, Bihar in Table 1. These genotypes were mated in half diallel fashion to obtain 45 direct crosses. During kharif 2015, the ten genotypes were crossed among themselves in diallel mating design (Griffing, Model-I, Method-II) and thus 45 direct crosses were obtained. These $45 \mathrm{~F}_{1}$ 's hybrids along with 10 parents including checks (Sahbhagi dhan) obtained from these crossing programme were sown on 24 June 2016, eighteen days old seedling were transplanted under drought condition (rain- out shelter) in randomized Block Design (RBD) with three replications. The total number of entries are 55 (45 crosses + 10 parents) including check. Sahbhagi dhan was used as standard checks. The experimental plot in each replication had two rows of two meter length with inter row and intra row spacing of $20 \mathrm{~cm}$ and $15 \mathrm{~cm}$, respectively. Eighteen days old seedlings were transplanted with single plant per hill .Recommended packages of practices were followed to raise a good crop.

\section{Chlorophyll content (SPAD)}

Leaf chlorophyll content was recorded by measuring leaf greenness using a portal chlorophyll meter (Monilta Camera Co. Ltd., Japan). This meter operates by clamping the sensor head on to a leaf blade. Leaf chlorophyll content was measured by light absorbance in the range of red and infrared. A silicon photodiode receptor converts the transmitted light to analogue electrical signals, which are then converted into digital signals and used by the microprocessor to calculate the dimensionless SPAD unit value. SPAD readings were collected from the middle region of first fully opened leaf from the top in five randomly selected plants of each genotype and they were averaged across each plot and expressed as SPAD reading per plant.

\section{Relative water content in flag leave (\%)}

Five fully expanded leaves were taken randomly from flag leaves of selected plants 
of rice. Fresh weight (FW) of the flag leaves was measured immediately with an electronic balance and immersed in the distilled water for 12 hours so that they became fully turgid. The flag leaves were dried with blotting paper and turgid weight (TW) was recorded. Afterward, leaves were placed in Kraft paper bags and kept in oven for 24 hours at $800 \mathrm{C}$ and dried weight (DW) was recorded. Leaf relative water content (RWC) of the flag leaves was determined using the equation given by Barr and Weatherley (1962).

$\mathrm{RWC}=\frac{\mathrm{F} \cdot \mathrm{W}-\mathrm{D} \cdot \mathrm{W} .}{\mathrm{T} \cdot \mathrm{W} \cdot-\mathrm{D} \cdot \mathrm{W} .} \times 100$

Where,

F.W. = Fresh Weight of flag leaf $(\mathrm{g})$

D.W. = Dry Weight of flag leaf $(\mathrm{g})$

T.W. = Turgid Weight of flag leaf $(\mathrm{g})$

\section{Harvest index (\%)}

Harvesting index is the ratio of economical yield to biological yield and it was calculated by using the following formula.

Harvest index $=$

$\frac{\text { Grain yield }}{\text { Totalbiologica yield (grain yield }+ \text { straw })} \times 100$

\section{Diallel cross}

The ten genotypes were crossed in diallel fashion to produce $\mathrm{F} 1$ seed in all possible combination excluding the reciprocal crosses during the year 2015. The seeds of F1 and their parents were grown in the rainout shelter in pots with RBD replicated trial under water stress condition to determine better parent heterosis and standard heterosis.

A replication comprised of 55 entries (45 F1s+ parents). Data was recorded of each parent plant and their respective cross on the basis of following observations days to fifty per cent flowering, plant height, chlorophyll content, tillers per plant, relative water content, panicle length, grains per panicle, 1000 grain weight, harvest index and yield per plant.

\section{Statistical analysis}

The data recorded on the $45 \mathrm{~F} 1$ hybrids and 10 parents were subjected to statistical analysis SAS version 9.2. Combining ability was also calculated by Grifing's approach (1956) Mid parent heterosis and better parent heterosis were calculated by using different formulas.

\section{Estimation of relative heterosis, heterobeltiosis and economic (standard) heterosis}

Percent increase or decrease of $F_{1}$ over mid parent, better parent and standard check has been referred as heterosis, heterobeltiosis and economic heterosis, respectively.

Heterosis (over mid parent), heterobeltiosis (over better parent) and economic heterosis (standard heterosis) was calculated as per procedure suggested by Shull (1908), Fonseca and Patterson (1968) and Meredith and Bridge (1972), respectively for individual as well as over the environments.

\section{Relative heterosis}

$$
\operatorname{Heterosis}(\%)=\frac{\overline{F_{1}}-\overline{M P}}{\overline{M P}} \times 100
$$

Significance of heterosis was tested by using student " $t$ " test.

Where,

$$
t_{(r-1)(g-1)}=\frac{\overline{F_{1}}-\overline{M P}}{S E_{\left(\overline{F_{1}}-\overline{M P}\right)}}
$$

$$
\begin{array}{lll}
\mathrm{F}_{1} & = & \text { Mean Value of } \mathrm{F}_{1} \\
\mathrm{MP} & = & \text { Mean mid parent value }
\end{array}
$$$$
\text { i.e. }\left(\mathrm{P}_{1}+\mathrm{P}_{2}\right) / 2
$$ 
Where,

$$
S E_{\left(\overline{F_{1}}-\overline{M P}\right)}=\sqrt{\frac{3 E M S}{2 r}}
$$

$$
\begin{aligned}
\text { EMS } & =\text { Error mean square } \\
r & =\text { Number of replications }
\end{aligned}
$$

\section{Heterobeltiosis}

$$
\text { Heterobeltiosis }=\frac{\left(\overline{F_{1}}-\overline{B P}\right)}{\overline{B P}}
$$

Significance of heterobeltiosis was tested by using student " $t$ " test

$$
t_{(r-1)(g-1)}=\frac{\overline{F_{1}}-\overline{B P}}{S E_{\left(\overline{F_{1}}-\overline{B P}\right)}}
$$

Where,

$$
\begin{aligned}
& \mathrm{BP}=\text { Value of better parent } \\
& S E_{\left(\overline{F_{1}}-\overline{B P}\right)}=\sqrt{\frac{2 E M S}{r}}
\end{aligned}
$$

\section{Standard heterosis}

$$
\text { Standard heterosis }=\frac{\left(\overline{F_{1}}-\overline{B C}\right)}{\overline{B C}}
$$

Significance of economic heterosis was tested by using student " $\mathrm{t}$ " test.

$$
t_{(r-1)(g-1)}=\frac{\overline{F_{1}}-\overline{B C}}{S E_{\left(\overline{F_{1}}-\overline{B C}\right)}}
$$

Where,

$\mathrm{BC}=$ Value of standard check/best check

$$
S E_{\left(\overline{F_{1}}-\overline{B C}\right)}=\sqrt{\frac{2 E M S}{r}}
$$

Heterosis in positive direction was considered desirable for all the characters except traits like days to $50 \%$ flowering and plant height where negative direction was considered desirable.

\section{Results and Discussion}

The analysis of variance was carried out to partition the total variance in to variance due to genotype and other sources for all characters. Mean sum of square due to treatment were found highly significant for all the morpho-physiological characters studied, indicating presence of ample amount of variability among the treatment (Table 2).

The analysis of variance of the experimental material generated through 10 x 10 half diallel crosses for days to 50 per cent flowering, plant height, chlorophyll content, tillers per plant, relative water content in flag leaf (\%), panicle length $(\mathrm{cm})$, grains per panicle, 1000grain weight $(\mathrm{g})$, harvest index and grain yield per plant. Perusal of the data revealed significant variability for all the characters. Highly significant differences were found among the parents and their crosses for all the traits, indicating that the material selected were diverse for all the traits and also resulted in creation of substantial genetic variability in the crosses. The mean sum of squares for genotypes and hybrids were highly significant for all the characters for all the crosses generated through diallel experiment.

Heterosis is a complex genetical phenomenon which depends upon the balance of additive, dominance and interaction components as well as the distribution of genes in the parental lines. Heterosis breeding is primarily based on the identification of parents and their cross combinations capable of producing the highest level of transgressive seggregants. The magnitude of heterosis depends on the extent of genetic diversity between parents and helps in choosing the parents for superior $\mathrm{F}_{1}$.

In the present investigation, two types of heterosis viz., heterobeltiosis (HB) and economic heterosis or standard heterosis $(\mathrm{SH})$ have been calculated. The magnitude of heterosis have been expressed as per cent increase or decrease of $F_{1}$ value over better parent (heterobeltiosis) and over standard 
check (standard or economic heterosis). The character wise results of better parent and economic heterosis are presented in Tables 36 . For all the characters, positive values were considered desirable whereas. For days to 50 per cent flowering and plant height negative values were considered desirable for calculating heterobeltiosis and economic heterosis. Commercial exploitation of hybrid vigoris feasible only if the vigor is in excess of prevailing commercial check and better parent.

One of the major objectives in plant breeding is to get higher grain yield per plant, therefore, emphasis was given in the present study for heterosis over better parent and standard check. The trait wise results are summarized as under:

The knowledge of heterosis with inbreeding depression would help in elimination of poor crosses in early stages. The magnitude of heterosis varied from cross to cross for all the characters studied, of these, the character of economic importance for rice is grain yield and the heterotic response obtained for this character is of greater importance for the purpose of practical plant breeding. The measure of heterosis over better parent and standard check (Sahbhagi dhan) is of much practical importance. In present investigation, therefore, the heterosis has been measured over the better parent and standard check. Thus, the aim of heterosis analysis in the present study was to search out the best combination of parents giving high degree of useful heterosis and characterization of parents for their prospects for future use in breeding programme. A large number of hybrids had significant desired heterosis over the better parent as well as standard check for various traits.

The present study is an attempt to assess the possibilities of commercial exploitation of heterosis and to develop better varieties and elite lines for further breeding programme. The results revealed wide range of heterotic patterns for all the traits studied. None of the cross combination recorded significant heterosis for all the traits simultaneously. These results are in agreement with the findings of Alam et al., (2004); Rashid et al., (2007); Parihar and Pathak (2008); Neelam et al., (2009); Kumar et al., (2010); Najeeb et al., (2011) and Dwivedi and Pandey (2012).

For grain yield per plant the range of heterobeltiosis varied from $-52.62 * *$ (IR $64 \mathrm{X}$ Vandana) to $83.87 * *$ (RAU-1415-35-76-9-53-4 X Dhanlaxmi). Twelve cross combinations out of 45 recorded significant and positive heterobeltiosis over best parents. For standard heterosis the spectrum of variation ranged from $-31.59 * *$ (RAU 145166-1-1-5-1 X IR 64) to 109.86** (IR87707182-B-B-B X Sahbhagi dhan). Out of 45 crosses, 19 cross exhibited significant positive standard heterosis for grain yield per plant. Most of the crosses which showed significant and positive heterosis for grain yield also showed significant and positive heterosis for most of the yield attributing characters. For example the cross IR87707-182-B-B-B X Sahbhagi dhan showed significant and positive heterobeltiosis and standard heterosis for seed yield also showed significant and positive standard heterosis for grains per panicle. The cross combination RAU1415-3576-9-5-3-4 X IR87707-182-B-B-B showed significant and positive heterobeltiosis and standard heterosis for seed yield also showed significant standard heterosis for days to fifty per cent flowering and chlorophyll content. The cross RAU1421-12-1-7-3 X Sahbhagi dhan showed significant and positive heterobeltiosis and standard heterosis for seed yield also showed significant standard heterosis for days to fifty per cent flowering, chlorophyll content, relative water content and grains per panicle. The cross IR87707182-B-B-B X Richharia showed significant and positive standard heterosis for seed yield 
also showed significant and positive standard heterosis for relative water content, panicle length, and grains per panicle, while RAU1415-35-76-9-5-3-4 X Dhanlaxmi showed significant and positive heterobeltiosis and standard heterosis for seed yield. This cross also showed significant and positive standard heterosis for chlorophyll content, tillers per plant and grains per panicle. The cross combination RAU1451-661-1-5-1 X Vandana, may be selected for higher grain yield per plant, early flowering and high relative water content, it showed significant and positive standard heterosis for these traits.

The cross RAU1451-66-1-1-5-1 X RAU141535-76-9-5-3-4 showed significant and positive heterobeltiosis and standard heterosis for seed yield per plant, it also showed significant and positive standard heterosis for days to fifty per cent flowering, plant height, chlorophyll content, tillers per plant, grains per panicle and harvest index, which is desirable under drought stress condition. So, this cross may be selected as promising and can be utilized in future breeding programme for drought stress condition. Some crosses did better than the average grain yield per plant of their parents.

This showed the existence of dominance or non-additive gene actions. These findings are in close agreement with the various workers who reported a standard heterosis of more than 20 per cent for grain yield increase over standard variety. Annadhurai and Nadarajan (2001), Janardhanam et al., (2001), Yadav et al., (2004), Datt and Mani (2004), Bhandarker et al., (2005), Malini et al., (2006), Eradasappa et al., (2007), Parihar and Pathak (2008), Venkatesan et al., (2008), Roy et al., (2009), Kumar et al., (2010), Tiwari et al., (2011) and Kumar et al.,(2012), Dwivedi and Pandey, (2012).

For days to 50 per cent flowering the heterotic effects of 10 crosses out of 45 crosses showed increase over better parental values and these 10 crosses were found to be negative significant, and the heterosis ranged from $4.37 * \%$ (Vandana X Richharia) to $-13.48 * * \%$ (RAU-1415-35-76-9-5-3-4 X IR 64). The range of positive heterosis was found to $0.00 \%$ (IR87707-182-B-B-B X Vandana) to $16.38 \%$ (RAU 1421-12-1-7-3 X Vandana). The overall range of heterobeltiosis was found to be from $-13.48 * * \%$ (RAU-1415-3576-9-5-3-4 X IR 64) to $16.38 \%$ (RAU 142112-1-7-3 X Vandana). 24 crosses out of 45 crosses showed positive heterobeltiosis and 11 crosses out of 24 were found to be significant. Significant negative standard heterosis over standard check, Sahbhagi dhan. Standard heterosis for days to $50 \%$ flowering ranged from -18.28** (RAU 1451-66-1-1-5-1 X RAU-1415-35-76-9-5-3-4 \$ RAU-1415-3576-9-5-3-4 X RAU 1421-12-1-7-3) to 2.99 (IR87707-182-B-B-B X IR 64). Thirty eight crosses showed negative and significant Stander heterosis for days to $50 \%$ flowering. Out of 45 crosses, 10 crosses revealed desirable heterobeltiosis and standard heterosis. Some of the crosses manifested significant positive heterobeltiosis, while others exhibited low negative values, probably due to the varying extent of genetic diversity between parents of different crosses for the component characters. Early flowering in hybrids had been reported by Lokaparkash et al., (1992), Patil et al., (2003) and Kumar et al., (2010). Shorter plant type is an important character of hybrid to withstand lodging. High desirable heterobeltiosis for plant height was observed in the cross combination IR 64 X Richharia.

For plant height, heterobeltiosis ranged from $16.61 * *$ (IR $64 \mathrm{X}$ Richharia) to $49.72 * *$ (IR87707-182-B-B-B X Vandana). Out of 45 crosses 9 cross combinations exhibited negative and significant heterobeltiosis. Standard heterosis for plant height ranged from -20.36** (RAU 1451-66-1-1-5-1 X IR $64)$ to $52.75^{* *}$ (IR87707-182-B-B-B X 
Vandana). Nine crosses showed negative and significant Stander heterosis for plant height. Maximum desirable standard heterosis for plant height was observed in the cross
RAU1451-66-1-15-1 x IR64 compared to the standard check. Luat et al., (1985), Rao et al., (1996) and Kumar et al., (2010). Also observed negative heterosis for plant height.

Table.1 List of parental genotypes

\begin{tabular}{|c|l|}
\hline Sl. No. & Genotypes \\
\hline 1 & RAU 1451-66-1-1-5-1 \\
\hline 2 & RAU-1415-35-76-9-5-3-4 \\
\hline 3 & RAU 1421-12-1-7-3 \\
\hline 4 & IR87707-182-B-B-B \\
\hline 5 & IR 64 \\
\hline 6 & Vandana \\
\hline 7 & Rasi \\
\hline 8 & Dhanlakhmi \\
\hline 9 & Richharia \\
\hline 10 & Sahbhagi Dhan \\
\hline
\end{tabular}

Table.2 Analysis of variance for diallel mating desing (Method II, Model I) for fifteen quantitative characters

\begin{tabular}{|c|c|c|c|c|c|c|c|}
\hline \multirow{2}{*}{$\begin{array}{l}\text { Sl. } \\
\text { No }\end{array}$} & \multirow[b]{2}{*}{ Characters } & \multicolumn{6}{|c|}{ Mean sum of square } \\
\hline & & Rep & Genotypes & Parent & Crosses & $\begin{array}{c}\text { Parent } \\
\text { VS } \\
\text { Crosses }\end{array}$ & Error \\
\hline & Df & 2.00 & 54.00 & 9.00 & 44.00 & 1.00 & 108.00 \\
\hline $\mathbf{1}$ & Days to fifty percent flowering (d) & $\mathbf{1 1 1 . 4 4}$ & $66.71 * * 1 * *$ & $72.83 * *$ & $58.40 * *$ & $190.41 * *$ & 3.85 \\
\hline 2 & Plant height $(\mathrm{cm})$ & 15.24 & $532.39 * *$ & $311.70 * *$ & $581.09 * *$ & $904.95 * *$ & 27.45 \\
\hline 3 & Chlorophyll content (SPAD) & 9.26 & $43.67 * *$ & $32.57 * *$ & $44.77 * *$ & $5.66^{* *}$ & 7.63 \\
\hline 4 & Tillers per plant & 1.80 & $15.43 * *$ & 2.53 & $16.57 * *$ & $92.45 * *$ & 1.83 \\
\hline 7 & Relative water content (\%) & 0.32 & $28.80 * *$ & $17.20 * *$ & $30.40 * *$ & $28.25 * *$ & 10.07 \\
\hline 8 & Panicle length $(\mathrm{cm})$ & 032 & $9.80 * *$ & $11.23 * *$ & $9.77 * *$ & $15.01 * *$ & 1.76 \\
\hline 12 & Grains per panicle (no) & 75.62 & $1327.96 * *$ & $1300.37 * *$ & $1393.11 * *$ & $397.83 * *$ & 26.44 \\
\hline 13 & 1000- grain weight $(\mathrm{g})$ & 6.18 & $11.24 * *$ & 6.40 & $12.66^{* *}$ & 0.03 & 5.46 \\
\hline 14 & Harvest index & 34.30 & $105.91 * *$ & 26.37 & $122.67 * *$ & 1.24 & 26.01 \\
\hline 15 & Grain yield per plant (g) & 2.99 & $200.17 * *$ & $161.61 * *$ & $210.64 * *$ & $424.09 * *$ & 9.40 \\
\hline
\end{tabular}


Table.3 Extant of heterosis for days to 50\% flowering, plant height and chlorophyll content

\begin{tabular}{|c|c|c|c|c|c|c|c|}
\hline \multirow[t]{2}{*}{ SI. No } & \multirow[t]{2}{*}{ Crosses } & \multicolumn{2}{|c|}{ DFF } & \multicolumn{2}{|c|}{$\mathbf{P H}$} & \multicolumn{2}{|c|}{$\mathrm{CC}$} \\
\hline & & HB & SH & HB & SH & HB & SH \\
\hline 1 & P1 X P2 & -2.67 & $-18.28 * *$ & -0.91 & $-14.89 * *$ & -6.97 & $14.43^{*}$ \\
\hline 2 & P1 X P3 & 1.77 & $-14.18 * *$ & 2.59 & -5.63 & 3.43 & $19.08^{* *}$ \\
\hline 3 & P1 X P4 & 1.59 & $-4.85^{* *}$ & $-11.89 * *$ & $-11.65^{* *}$ & -8.72 & 5.09 \\
\hline 4 & P1 X P5 & $-7.12 * *$ & $-7.46 * *$ & -7.09 & $-20.36^{* *}$ & -7.93 & 6.00 \\
\hline 5 & P1 X P6 & 3.88 & $-10.07 * *$ & 4.19 & 6.30 & $-26.66 * *$ & $-15.57^{*}$ \\
\hline 6 & P1 X P7 & 0.88 & $-14.55^{* *}$ & $10.26^{*}$ & -2.45 & 5.19 & $26.42 * *$ \\
\hline 7 & P1 X P8 & -1.27 & $-13.06^{* *}$ & -6.53 & $-10.21^{*}$ & -1.05 & $21.88^{* * *}$ \\
\hline 8 & P1 X P9 & -3.17 & $-8.96 * *$ & $-13.81 * *$ & 0.74 & -0.15 & $14.97 *$ \\
\hline 9 & P1 X P10 & $6.33 * *$ & $-5.97 * *$ & 6.37 & 3.00 & -5.59 & $13.95^{*}$ \\
\hline 10 & P2 X P3 & -3.10 & $-18.28 * *$ & -4.95 & $-12.56^{* *}$ & $-12.51 *$ & 7.62 \\
\hline 11 & P2 X P4 & -2.39 & $-8.58 * *$ & -6.55 & -6.30 & -5.34 & 16.44* \\
\hline 12 & P2 X P5 & $-13.48 * *$ & $-13.81 * *$ & -2.23 & $-16.03 * *$ & 8.75 & $33.77 * *$ \\
\hline 13 & P2 X P6 & 0.86 & $-12.69 * *$ & 5.35 & 7.48 & -6.15 & $15.44 *$ \\
\hline 14 & P2 X P7 & 3.52 & $-12.31 * *$ & 4.29 & -7.73 & 0.57 & $23.70 * *$ \\
\hline 15 & P2 X P8 & 0.42 & $-11.57 * *$ & -1.54 & -5.42 & 1.91 & $25.52 * *$ \\
\hline 16 & P2 X P9 & $-4.76^{*}$ & $-10.45^{* *}$ & $-12.71^{* *}$ & 2.02 & -1.50 & $21.16^{* *}$ \\
\hline 17 & P2 X P10 & $4.64 *$ & $-7.46^{* *}$ & -6.63 & $-9.58 *$ & -6.32 & $15.23^{*}$ \\
\hline 18 & P3 X P4 & $6.77 * *$ & 0.00 & 5.43 & 5.72 & -6.31 & -1.67 \\
\hline 19 & P3 X P5 & $-5.24 * *$ & $-5.60 * *$ & 2.75 & -5.47 & $15.23 *$ & $20.94 * *$ \\
\hline 20 & P3 X P6 & $16.38 * *$ & 0.75 & $41.21 * *$ & $44.07 * *$ & $-20.52 * *$ & -9.75 \\
\hline 21 & P3 X P7 & $7.05 * *$ & $-9.33 * *$ & $11.01 *$ & 2.12 & $16.43 * *$ & $39.92 * *$ \\
\hline 22 & P3 X P8 & $5.51 * *$ & $-7.09 * *$ & -0.94 & -4.85 & -1.53 & $21.29 * *$ \\
\hline 23 & P3 X P9 & 1.19 & $-4.85 * *$ & -6.31 & $9.50 *$ & 2.69 & $18.24 * *$ \\
\hline 24 & P3 X P10 & $6.33^{* *}$ & $-5.97 * *$ & 4.37 & 1.07 & -5.98 & $13.49 *$ \\
\hline 25 & P4 X P5 & 3.37 & 2.99 & $-9.83 *$ & $-9.58 *$ & 9.48 & $14.40^{*}$ \\
\hline 26 & P4 X P6 & 0.00 & $-6.34 * *$ & $49.72 * *$ & $52.75^{* *}$ & -3.95 & 9.07 \\
\hline 27 & P4 X P7 & $-7.97 * *$ & $-13.81 * *$ & -2.10 & -1.83 & 6.03 & $27.42 * *$ \\
\hline 28 & P4 X P8 & -1.99 & $-8.21 * *$ & -1.12 & -0.85 & -6.21 & $15.53 *$ \\
\hline 29 & P4 X P9 & $9.13^{* *}$ & 2.61 & $-13.76^{* *}$ & 0.79 & -10.32 & 3.27 \\
\hline 30 & P4 X P10 & 3.59 & -2.99 & -5.10 & -4.84 & -7.67 & 11.44 \\
\hline 31 & P5 X P6 & $-9.74 * *$ & $-10.07 * *$ & $11.44 * *$ & $13.69 * *$ & 11.05 & $26.10 * *$ \\
\hline 32 & P5 X P7 & $-7.12^{* *}$ & $-7.46^{* *}$ & 7.38 & -5.00 & -8.92 & 9.46 \\
\hline 33 & P5 X P8 & $-8.99 * *$ & $-9.33 * *$ & -3.51 & -7.31 & 3.34 & $27.29 * *$ \\
\hline 34 & P5 X P9 & -1.87 & -2.24 & $-16.61 * *$ & -2.53 & 0.57 & $15.81 *$ \\
\hline 35 & P5 X P10 & -0.75 & -1.12 & $21.35 * *$ & $17.51 * *$ & $-20.89 * *$ & -4.51 \\
\hline 36 & P6 X P7 & $6.03 * *$ & $-8.21 * *$ & -6.10 & -4.20 & $-16.15^{* *}$ & 0.76 \\
\hline 37 & P6 X P8 & $4.24 *$ & $-8.21 * *$ & $-10.48^{*}$ & $-8.67 *$ & -7.87 & $13.49 *$ \\
\hline 38 & P6 X P9 & $-4.37^{*}$ & $-10.07^{* *}$ & 2.39 & $19.68 * *$ & 6.84 & $23.03^{* * *}$ \\
\hline 39 & P6 X P10 & -2.11 & $-13.43 * *$ & 2.16 & 4.23 & -0.35 & $20.28 * *$ \\
\hline 40 & P7 X P8 & $5.08^{*}$ & $-7.46 * *$ & 8.30 & 4.03 & $-15.60 * *$ & 3.96 \\
\hline 41 & P7 X P9 & 0.79 & $-5.22 * *$ & -2.51 & $13.95^{* *}$ & -5.72 & $13.30^{*}$ \\
\hline 42 & P7 X P10 & $-4.64 *$ & $-15.67 * *$ & $9.57 *$ & 6.11 & -3.23 & $16.80^{* * *}$ \\
\hline 43 & P8 X P9 & -1.98 & $-7.84 * *$ & $-9.77 * *$ & 5.46 & -0.87 & $22.10 * *$ \\
\hline 44 & P8 X P10 & 3.38 & $-8.58^{* *}$ & -3.68 & -6.73 & -0.83 & $22.15^{* * *}$ \\
\hline 45 & P9 X P10 & -2.38 & $-8.21 * *$ & $-13.93 * *$ & 0.60 & -6.04 & $13.41 *$ \\
\hline
\end{tabular}

\footnotetext{
$*$ and $* *$ Significant at 5 and 1 per cent respectively
} 
Table.4 Extant of heterosis for tillers per plant, relative water content and panicle length

\begin{tabular}{|c|c|c|c|c|c|c|c|}
\hline \multirow[t]{2}{*}{ Sl. No } & \multirow[t]{2}{*}{ Crosses } & \multicolumn{2}{|c|}{ TPP } & \multicolumn{2}{|c|}{ RWC } & \multicolumn{2}{|c|}{$\mathbf{P L}$} \\
\hline & & HB & SH & HB & SH & HB & SH \\
\hline 1 & P1 X P2 & $94.44 * *$ & $66.67 * *$ & -1.91 & 5.64 & -6.79 & -1.99 \\
\hline 2 & P1 X P3 & $94.44 * *$ & $66.67 * *$ & 5.53 & $10.78 * *$ & $10.10^{*}$ & $16.02 * *$ \\
\hline 3 & P1 X P4 & $55.56 * *$ & $33.33 *$ & -5.64 & -0.95 & 7.74 & 7.44 \\
\hline 4 & P1 X P5 & $73.91 * *$ & $90.48^{* *}$ & 0.43 & 5.42 & -5.21 & 1.80 \\
\hline 5 & P1 X P6 & $44.44 *$ & 23.81 & 1.33 & $8.05 * *$ & -5.11 & 1.96 \\
\hline 6 & P1 X P7 & $72.73 * *$ & $80.95 * *$ & 3.85 & $9.01 * *$ & -3.65 & -3.91 \\
\hline 7 & P1 X P8 & $83.33 * *$ & $57.14 * *$ & 1.78 & $6.84 *$ & $-13.11 * *$ & $-13.34 * *$ \\
\hline 8 & P1 X P9 & -13.04 & -4.76 & -5.67 & -0.98 & -0.97 & 7.54 \\
\hline 9 & P1 X P10 & $31.82 *$ & $38.10 *$ & 2.81 & $7.93 * *$ & -7.91 & 0.00 \\
\hline 10 & P2 X P3 & $58.82 * *$ & 28.57 & -4.90 & 2.42 & 0.00 & 3.86 \\
\hline 11 & $\mathrm{P} 2 \mathrm{X} \mathrm{P} 4$ & 22.22 & 4.76 & -4.03 & 3.35 & -4.81 & 0.10 \\
\hline 12 & P2 X P5 & -8.70 & 0.00 & -4.67 & 2.67 & -2.12 & 5.13 \\
\hline 13 & P2 X P6 & 23.53 & 0.00 & $-8.82 * *$ & -1.80 & -3.26 & 3.94 \\
\hline 14 & P2 X P7 & 9.09 & 14.29 & -1.58 & 6.00 & -7.24 & -2.46 \\
\hline 15 & P2 X P8 & $155.56^{* *}$ & $119.05 * *$ & $-6.90 *$ & 0.26 & -2.20 & 2.84 \\
\hline 16 & P2 X P9 & $43.48 * *$ & $57.14 * *$ & -4.58 & 2.76 & 1.91 & $10.67 *$ \\
\hline 17 & P2 X P10 & $54.55 * *$ & $61.90 * *$ & -0.81 & $6.83^{*}$ & -2.04 & 3.00 \\
\hline 18 & P3 X P4 & -11.11 & -23.81 & -6.11 & -3.11 & -7.12 & -2.13 \\
\hline 19 & P3 X P5 & 13.04 & 23.81 & $8.90^{* *}$ & $10.23 * *$ & 4.70 & $12.44 * *$ \\
\hline 20 & P3 X P6 & 29.41 & 4.76 & 1.12 & $7.84 * *$ & $15.78 * *$ & $24.40 * *$ \\
\hline 21 & P3 X P7 & -9.09 & -4.76 & 0.18 & 1.89 & -7.62 & -2.66 \\
\hline 22 & P3 X P8 & 0.00 & -14.29 & 5.97 & $8.04 * *$ & -6.44 & -1.41 \\
\hline 23 & P3 X P9 & -17.39 & -9.52 & 0.57 & 2.03 & -5.26 & 2.89 \\
\hline 24 & P3 X P10 & 9.09 & 14.29 & 8.95 & $10.28 * *$ & 3.43 & -3.36 \\
\hline 25 & P4 X P5 & 4.35 & 14.29 & 6.10 & $9.49 * *$ & -1.52 & 5.77 \\
\hline 26 & P4 X P6 & $55.56 * *$ & $33.33^{*}$ & 2.19 & $8.98 * *$ & 7.75 & $15.77 * *$ \\
\hline 27 & P4 X P7 & 18.18 & 23.81 & 6.18 & $9.57 * *$ & 0.74 & -1.40 \\
\hline 28 & P4 X P8 & $38.89 *$ & 19.05 & -1.40 & 1.75 & -1.69 & -3.79 \\
\hline 29 & P4 X P9 & -26.09 & -19.05 & 4.90 & $8.25 * *$ & 2.62 & $11.44 * *$ \\
\hline 30 & P4 X P10 & 4.55 & 9.52 & -1.38 & 1.77 & 7.15 & 3.44 \\
\hline 31 & P5 X P6 & -26.09 & -19.05 & 1.59 & $8.33 * *$ & -0.80 & 6.59 \\
\hline 32 & P5 X P7 & -13.04 & -4.76 & $7.89 *$ & $9.73 * *$ & -5.85 & 1.11 \\
\hline 33 & P5 X P8 & -8.70 & 0.00 & -4.73 & -2.86 & $-11.13^{* *}$ & -4.56 \\
\hline 34 & P5 X P9 & -21.74 & -14.29 & 5.09 & $6.62 *$ & 6.56 & $15.73 * *$ \\
\hline 35 & P5 X P10 & 13.04 & 23.81 & 2.55 & 2.55 & 7.15 & $10.50 *$ \\
\hline 36 & P6 X P7 & -22.73 & -19.05 & -5.85 & 0.40 & -6.30 & 0.67 \\
\hline 37 & P6 X P8 & $72.22 * *$ & $47.62 * *$ & -0.80 & 5.79 & $-12.89 * *$ & -6.40 \\
\hline 38 & P6 X P9 & $52.17 * *$ & $66.67 * *$ & $-8.18^{*}$ & -2.09 & $10.71 *$ & $20.23 * *$ \\
\hline 39 & P6 X P10 & 0.00 & 4.76 & -3.29 & 3.13 & 3.99 & $11.73 * *$ \\
\hline 40 & P7 X P8 & $36.36^{*}$ & $42.86^{* *}$ & 1.20 & 3.18 & $17.51 * *$ & 5.10 \\
\hline 41 & P7 X P9 & 4.35 & 14.29 & 1.02 & 2.75 & $8.93 *$ & $18.30 * *$ \\
\hline 42 & P7 X P10 & -13.64 & -9.52 & 5.96 & $7.78 * *$ & $1.29 *$ & $10.30 *$ \\
\hline 43 & P8 X P9 & -13.04 & -4.76 & -3.24 & -1.34 & 2.35 & $11.16^{* *}$ \\
\hline 44 & P8 X P10 & -27.27 & -23.81 & 4.68 & $6.73^{*}$ & 7.46 & 7.44 \\
\hline 45 & P9 X P10 & -17.39 & -9.52 & $6.94 *$ & $8.80 * *$ & -1.85 & 6.59 \\
\hline
\end{tabular}

$*$ and ** Significant at 5 and 1 per cent respectively 
Table.5 Extant of heterosis for grains per panicle, 1000- grain weight and harvest index

\begin{tabular}{|c|c|c|c|c|c|c|c|}
\hline \multirow[t]{2}{*}{ Sl. No } & \multirow[t]{2}{*}{ Crosses } & \multicolumn{2}{|l|}{ GPP } & \multicolumn{2}{|c|}{ 1000- GW } & \multicolumn{2}{|c|}{ HI } \\
\hline & & HB & SH & HB & SH & HB & SH \\
\hline 1 & P1 X P2 & 1.37 & $13.91 * *$ & $13.69 *$ & 14.65 & $20.49 *$ & $27.72 * *$ \\
\hline 2 & P1 X P3 & $19.40 * *$ & $34.56^{* * *}$ & -2.25 & 8.08 & $13.69 *$ & $25.34 * *$ \\
\hline 3 & P1 X P4 & $-7.92 *$ & 3.66 & -2.11 & 8.38 & 1.94 & 13.04 \\
\hline 4 & P1 X P5 & -3.28 & $8.85 *$ & $-35.41 * *$ & $-19.08 *$ & $-28.80 * *$ & $-21.83 * *$ \\
\hline 5 & P1 X P6 & $-11.23 * *$ & 2.06 & $11.00 *$ & 22.73 & 2.34 & 8.66 \\
\hline 6 & P1 X P7 & $7.92 *$ & 3.65 & 1.22 & 17.71 & $7.66^{*}$ & $22.12 * *$ \\
\hline 7 & P1 X P8 & $-23.22 * *$ & $-13.60^{* *}$ & 4.64 & 17.03 & $-40.96^{* *}$ & $-37.71 * *$ \\
\hline 8 & P1 X P9 & $-33.68 * *$ & $-21.87 * *$ & -3.23 & $19.97 *$ & $7.05 *$ & 5.57 \\
\hline 9 & P1 X P10 & $7.93^{*}$ & $21.51 * *$ & -2.04 & 8.33 & 17.94* & $17.93^{*}$ \\
\hline 10 & P2 X P3 & $-13.02 * *$ & -3.44 & 6.16 & 13.08 & 2.30 & 12.78 \\
\hline 11 & $\mathrm{P} 2 \mathrm{X} \mathrm{P} 4$ & $8.60 *$ & -2.03 & $16.28 *$ & 3.76 & $13.07 *$ & 14.30 \\
\hline 12 & P2 X P5 & 2.29 & $9.90 * *$ & -9.03 & 13.96 & $11.86^{*}$ & $22.81 * *$ \\
\hline 13 & P2 X P6 & 4.55 & $20.03 * *$ & -1.51 & 8.33 & 3.39 & 9.77 \\
\hline 14 & P2 X P7 & $-18.91 * *$ & $-13.01 * *$ & $-10.98 *$ & 3.52 & 1.88 & 15.57 \\
\hline 15 & P2 X P8 & $14.33 * *$ & $22.76^{* * *}$ & $13.10^{*}$ & 8.38 & $12.77 *$ & 8.92 \\
\hline 16 & P2 X P9 & $-11.75^{* *}$ & 3.94 & 2.50 & $27.07 *$ & 2.12 & 8.24 \\
\hline 17 & P2 X P10 & $-10.88 * *$ & -4.58 & 14.49 & $21.93 *$ & 2.90 & 9.06 \\
\hline 18 & P3 X P4 & $22.99 * *$ & $-14.24 * *$ & $19.00 *$ & $20.68 *$ & $11.25 *$ & 12.28 \\
\hline 19 & P3 X P5 & 2.77 & $13.93 * *$ & 1.43 & $27.08 *$ & 1.30 & 11.68 \\
\hline 20 & P3 X P6 & $8.29 *$ & $24.31 * *$ & $12.66^{*}$ & 12.91 & $12.88^{*}$ & 13.42 \\
\hline 21 & P3 X P7 & 5.54 & $17.14 * *$ & -1.40 & 14.67 & 2.75 & 16.55 \\
\hline 22 & P3 X P8 & $-19.67 * *$ & $-10.67 * *$ & -3.36 & 8.08 & -2.62 & 7.35 \\
\hline 23 & P3 X P9 & $41.25^{* *}$ & $-30.83^{* *}$ & $18.08 *$ & 13.96 & $8.13 *$ & 1.29 \\
\hline 24 & P3 X P10 & -1.66 & $9.30 * *$ & 12.20 & 13.08 & -8.72 & 0.63 \\
\hline 25 & P4 X P5 & 0.63 & -1.26 & $-36.71 * *$ & $-20.72 *$ & $-29.54 * *$ & $-21.87 * *$ \\
\hline 26 & P4 X P6 & $9.36^{* *}$ & $25.94 * *$ & 10.13 & $21.93 *$ & $-17.72 *$ & -8.75 \\
\hline 27 & P4 X P7 & $22.74 * *$ & $21.08 * *$ & 0.63 & 17.03 & -0.31 & 13.08 \\
\hline 28 & P4 X P8 & $-21.94 * *$ & $-23.41 * *$ & 7.27 & $19.97 *$ & -1.94 & 8.74 \\
\hline 29 & P4 X P9 & $26.63 * *$ & $-13.51 * *$ & $15.05^{*}$ & 17.72 & $17.60 *$ & 2.48 \\
\hline 30 & P4 X P10 & $73.54 * *$ & $73.53 * *$ & 3.54 & 14.65 & 4.22 & 7.05 \\
\hline 31 & P5 X P6 & $-8.56^{*}$ & 5.08 & $-17.18 *$ & 3.75 & $-18.69 *$ & -10.74 \\
\hline 32 & P5 X P7 & -0.31 & -1.66 & $-20.19^{* *}$ & -0.02 & $-28.58 * *$ & $-18.98 * *$ \\
\hline 33 & P5 X P8 & $20.07 * *$ & 3.02 & 0.59 & $26.02 *$ & $7.25 *$ & $17.75^{*}$ \\
\hline 34 & P5 X P9 & 1.04 & $18.90 * *$ & -2.03 & $22.73 *$ & $-13.63^{*}$ & -5.18 \\
\hline 35 & P5 X P10 & -0.61 & -0.72 & 1.46 & 12.22 & 3.06 & 8.90 \\
\hline 36 & P6 X P7 & $-13.37 * *$ & -0.18 & $-16.37 *$ & -2.75 & $-10.83^{*}$ & 1.15 \\
\hline 37 & P6 X P8 & $27.27 * *$ & $46.44 * *$ & $10.91 *$ & $24.04 *$ & -6.47 & -0.70 \\
\hline 38 & P6 X P9 & $20.89 * *$ & $42.34 * *$ & -9.79 & 11.83 & -6.24 & -0.45 \\
\hline 39 & P6 X P10 & $21.66^{* *}$ & $39.79 * *$ & 5.75 & 16.29 & 13.79 & $20.82 *$ \\
\hline 40 & P7 X P8 & $13.71 * *$ & $12.53 * *$ & -5.39 & 10.02 & -5.47 & 7.23 \\
\hline 41 & P7 X P9 & $-10.18 * *$ & 5.79 & 1.05 & $25.28 *$ & 0.11 & 13.55 \\
\hline 42 & P7 X P10 & -4.00 & -3.78 & -4.80 & 10.71 & -4.30 & 8.54 \\
\hline 43 & P8 X P9 & $10.70 * *$ & $30.56 * *$ & -7.94 & 14.13 & $10.11 *$ & 16.15 \\
\hline 44 & P8 X P10 & 2.27 & 2.56 & -0.39 & 11.42 & 9.12 & 15.79 \\
\hline 45 & P9 X P10 & -4.70 & 12.22 & -5.53 & 17.09 & 11.29 & 11.29 \\
\hline
\end{tabular}

\footnotetext{
$*$ and ** Significant at 5 and 1 per cent respectively
} 
Table.6 Extant of heterosis for grain yield per plant

\begin{tabular}{|c|c|c|c|c|}
\hline \multirow[t]{2}{*}{ Sl. No } & \multirow[t]{2}{*}{ Crosses } & \multicolumn{3}{|c|}{ GYP } \\
\hline & & RH & HB & SH \\
\hline 1 & P1 X P2 & $67.47 * *$ & $64.01 * *$ & $50.44 * *$ \\
\hline 2 & P1 X P3 & 5.63 & $-14.95^{*}$ & $27.83^{* *}$ \\
\hline 3 & P1 X P4 & $-18.31 *$ & $-33.38 * *$ & -3.15 \\
\hline 4 & P1 X P5 & $-36.73 * *$ & $-45.06 * *$ & $-31.59 * *$ \\
\hline 5 & P1 X P6 & $59.45 * *$ & $50.75^{* *}$ & $55.22 * *$ \\
\hline 6 & P1 X P7 & $67.06^{* *}$ & $30.09 *$ & 19.33 \\
\hline 7 & P1 X P8 & -8.42 & -17.53 & $-24.36 * *$ \\
\hline 8 & P1 X P9 & $21.50 *$ & 20.38 & 10.42 \\
\hline 9 & P1 X P10 & 52.48 & 46.19 & $46.20 * *$ \\
\hline 10 & P2 X P3 & $-24.14 * *$ & $-39.88 * *$ & -9.64 \\
\hline 11 & P2 X P4 & $57.62 * *$ & $26.47 * *$ & $83.87 * *$ \\
\hline 12 & P2 X P5 & -15.00 & $-27.49 * *$ & -9.71 \\
\hline 13 & P2 X P6 & $23.52 *$ & 14.50 & 17.90 \\
\hline 14 & P2 X P7 & $83.01 * *$ & $44.71 * *$ & $27.25 * *$ \\
\hline 15 & P2 X P8 & $100.35^{* *}$ & $83.87 * *$ & $61.68 * *$ \\
\hline 16 & P2 X P9 & 16.02 & 14.66 & 3.24 \\
\hline 17 & P2 X P10 & 27.22 & 19.55 & 19.54 \\
\hline 18 & P3 X P4 & $14.74 *$ & 12.86 & $69.63 * *$ \\
\hline 19 & P3 X P5 & -6.21 & -14.25 & $28.88 * *$ \\
\hline 20 & P3 X P6 & 13.14 & -4.67 & $43.28 * *$ \\
\hline 21 & P3 X P7 & $27.62 * *$ & $-14.49 *$ & $28.53 * *$ \\
\hline 22 & P3 X P8 & -2.20 & $-27.20 * *$ & 9.43 \\
\hline 23 & P3 X P9 & $22.38 * *$ & $20.27 * *$ & $47.07 * *$ \\
\hline 24 & P3 X P10 & $44.44 *$ & $20.28 * *$ & $80.78 * *$ \\
\hline 25 & P4 X P5 & $-47.12 * *$ & $-50.92 * *$ & $-28.64 * *$ \\
\hline 26 & P4 X P6 & -10.35 & $-23.43 * *$ & 11.32 \\
\hline 27 & P4 X P7 & -0.87 & $-33.00 * *$ & -2.60 \\
\hline 28 & P4 X P8 & 8.24 & $-18.53 *$ & 18.44 \\
\hline 29 & P4 X P9 & $38.58 * *$ & 12.20 & $63.13 * *$ \\
\hline 30 & P4 X P10 & $71.05 * *$ & $44.35^{* *}$ & $109.86^{* *}$ \\
\hline 31 & P5 X P6 & $-48.13 * *$ & $-52.62 * *$ & $-41.00^{* *}$ \\
\hline 32 & P5 X P7 & 15.68 & $-18.41 *$ & 1.60 \\
\hline 33 & P5 X P8 & -17.70 & $-34.57 * *$ & -18.53 \\
\hline 34 & P5 X P9 & -13.41 & $-25.40 * *$ & -7.11 \\
\hline 35 & P5 X P10 & $64.40 * *$ & $49.16^{* *}$ & $83.10^{* *}$ \\
\hline 36 & P6 X P7 & -12.27 & $-34.35 * *$ & $-32.41 * *$ \\
\hline 37 & P6 X P8 & -4.62 & -18.28 & -15.86 \\
\hline 38 & P6 X P9 & 18.37 & 10.94 & 14.23 \\
\hline 39 & P6 X P10 & 52.82 & $50.63 * *$ & $55.08 * *$ \\
\hline 40 & P7 X P8 & $31.91 *$ & 11.85 & -17.83 \\
\hline 41 & P7 X P9 & $30.89^{*}$ & 2.61 & -7.61 \\
\hline 42 & P7 X P10 & 64.97 & 24.65 & $24.67 * *$ \\
\hline 43 & P8 X P9 & $55.76 * *$ & $41.42 * *$ & $27.34 * *$ \\
\hline 44 & P8 X P10 & 17.69 & 2.06 & 2.05 \\
\hline 45 & P9 X P10 & 19.47 & 13.53 & 13.54 \\
\hline
\end{tabular}


For chlorophyll content heterobeltiosis and Standard heterosis ranged from -26.66** (RAU 1451-66-1-1-5-1 X Vandana) to 16.43** (RAU 1421-12-1-7-3 X Rasi) and 15.57* (RAU 1451-66-1-1-5-1 X Vandana) to 39.92** (RAU 1421-12-1-7-3 X Rasi), respectively. Only two crosses out of 45 exhibited significant positive heterobeltiosis for chlorophyll content, whereas 32 cross combinations exhibited significant positive Stander heterosis for chlorophyll content. Maximum heterobeltiosis and standard heterosis was exhibited by RAU 1421-12-1-73 X Rasi to an extent of $16.43 \%$ and $39.92 \%$ respectively.

For number of tillers per plant heterobeltiosis ranged from -27.27 (Dhanlaxmi X Sahbhagi dhan) to $155.56 * *$ (RAU-1415-35-76-9-5-3-4 $\mathrm{X}$ Dhanlaxmi). Out of 45 crosses 17 crosses exhibited positive significant heterobeltiosis for number of tillers per plant. Standard heterosis for number of tillers per plant ranged from -23.81 (RAU 1421-12-1-7-3 X IR87707-182-B-B-B and Dhanlaxmi $X$ Sahbhagi dhan) to $119.05^{* *}$ (RAU-1415-3576-9-5-3-4 X Dhanlaxmi). Fourteen crosses showed positive and significant Standard heterosis for number of tillers per plant. Maximum heterobeltiosis and standard heterosis was exhibited by RAU-1415-35-769-5-3-4 X Dhanlaxmi to an extent of $155.56 \%$ and $119.05 \%$ respectively. Datt and Mani (2004), Yadav et al., (2004), Pandya and Tripathi (2006), Eradasappa et al., (2007), Parihar and Pathak (2008) and Tiwari et al., (2011) also reported similar results in rice.

For relative water content Heterobeltiosis and Standard heterosis ranged from $-8.82 * *$ (RAU-1415-35-76-9-5-3-4 X Vandana) to 8.90** (RAU 1421-12-1-7-3 X IR 64) and 3.11 (RAU 1421-12-1-7-3 X IR87707-182-BB-B) to 10.78 (RAU 1451-66-1-1-5-1 X RAU 1421-12-1-7-3) respectively. Out of 45 crosses 3 crosses exhibited significant positive heterotic effects over their respective better parent. Whereas the 20 cross combinations were found Significant and positive standard heterosis over check Sahbhagi dhan for high chlorophyll content in leaves.

As regards to heterobeltiosis for panicle length, RAU 1451-66-1-1-5-1 X RAU 142112-1-7-3 (10.10*), RAU 1421-12-1-7-3 X Vandana (15.78**), Vandana X Richharia (10.71*), Rasi X Dhanlaxmi (17.51**), Rasi X Richharia $\left(8.93^{*}\right)$, Rasi X Sahbhagi dhan (1.29*), crosses expressed significant positive heterotic effect. Maximum and minimum heterobeltiosis was observed in the cross Rasi X Dhanlaxmi (17.51**) and RAU 1451-66-11-5-1 X Dhanlaxmi (-13.11**) respectively. For Standard heterosis its range varied from 13.34** (RAU 1451-66-1-1-5-1 X Dhanlaxmi) to $24.40 * *$ (RAU 1421-12-1-7-3 $\mathrm{X}$ Vandana), significant positive standard heterosis over standard check Sahbhagi dhan, were observed in RAU 1451-66-1-1-5-1 X RAU 1421-12-1-7-3 (16.02**), RAU-141535-76-9-5-3-4 X Richharia (10.67*), RAU 1421-12-1-7-3 X IR 64 (12.44**), RAU 1421-12-1-7-3 X Vandana (24.40**), IR87707-182-B-B-B X Vandana (15.77**), IR87707-182-B-B-B X Richharia (11.44**), IR 64 X Richharia (15.73**), IR 64 X Sahbhagi dhan (10.50*), Vandana X Richharia (20.23**), Vandana X Sahbhagi dhan (11.73**), Rasi X Richharia (18.30**), Rasi X Sahbhagi dhan (10.30*) and Dhanlaxmi X Richharia (11.16**) hybrids for panicle length.

For number of grains per panicle, Heterobeltiosis and standard heterosis ranged from -33.68** (RAU 1451-66-1-1-5-1 X Richharia) to $73.54 * *$ (IR87707-182-B-B-B $\mathrm{X}$ Sahbhagi dhan) and -23.41** (IR87707182-B-B-B X Dhanlaxmi) to $73.53 * *$ (IR87707-182-B-B-B X Sahbhagi dhan) respectively. Out of 45 crosses studied eighteen crosses exhibited significant positive heterotic effect over their respective better 
parent for grains per panicle. Out of 45 crosses 20 crosses exhibited significant positive standard heterosis over check Sahbhagi dhan.

For 1000- Grain weight heterobeltiosis ranged from -36.71** (IR87707-182-B-B-B X IR 64) to $19.00 * *$ (RAU 1421-12-1-7-3 X IR87707182-B-B-B). Out of 45 crosses, nine crosses exhibited significant heterobeltiosis in positive direction. Standard heterosis ranged from -20.72** (IR87707-182-B-B-B X IR 64) to 27.08* (RAU 1421-12-1-7-3 X IR 64). Eleven crosses out of 45 showed significant positive standard heterosis for 1000- Grain weight. The cross RAU 1421-12-1-7-3 X IR87707-182-B-B-B recorded the maximum heterobeltiosis, while the cross combination RAU1421-12-1-7-3 X IR64 recorded the maximum standard heterosis over the check Sahbhagi dhan. Results are in agreement with the findings of Datt and Mani (2004), Pandya and Tripathi (2006), Singh et al., (2007), Parihar and Pathak (2008), Roy et al., (2009), Tiwari et al., (2011) and Kumar et al., (2012).

For harvest index with regards to heterobeltiosis, its range varied from $-40.96 * *$ (RAU 1451-66-1-1-5-1 X Dhanlaxmi) to 20.49* (RAU 1451-66-1-1-5-1 X RAU-141535-76-9-5-3-4). Standard heterosis for harvest index ranged from $-37.71 * *$ (RAU 1451-661-1-5-1 X Dhanlaxmi) to 27.72** (RAU 1451-66-1-1-5-1 X RAU-1415-35-76-9-5-34). Maximum desirable heterobeltiosis and standard heterosis for harvest index was observed in the cross RAU 1451-66-1-1-5-1 X RAU-1415-35-76-9-5-3-4, along with yield and most of the yield attributing traits. Out of 45 crosses, 14 and 7 crosses revealed desirable heterobeltiosis and standard heterosis respectively. Some of the crosses manifested significant negative heterobeltiosis, while others exhibited low positive values, probably due to the varying extent of genetic diversity between parents of different crosses for the component characters. These findings are uniformity with the results reported by kumar et al., (2010).

The exploitation of heterosis in crop plant is regarded as one of the major breakthrough in the field of plant breeding. The application of heterosis is considered to be an outstanding application of principles of genetics to agriculture. The scope of exploitation of hybrid vigour depends on directions and magnitude of heterosis and type of gene action involved.

In present study, the magnitude of the heterosis varied from cross to cross. The top 5 crosses viz., IR87707-182-B-B-B X Sahbhagi dhan, RAU-1415-35-76-9-5-3-4 X IR87707182-B-B-B, IR $64 \mathrm{X}$ Sahbhagi dhan, RAU1421-12-1-7-3 X Sahbhagi dhan and RAU 1421-12-1-7-3 X IR87707-182-B-B-B, showed high significant positive standard heterosis over the check Sahbhagi dhan for grain yield and various yield component characters.

In general, considerable heterobeltiosis and standard heterosis observed for grain yield per plant and other associated characters suggested the presence of large genetic diversity among the parental genotype and also the unidirectional distribution of allelic constitution contributing towards desirable heterosis in the present material. The negative heterobeltiosis and standard heterosis and expressed by a number of crosses for characters such as days to 50 per cent flowering and plant height suggested that hybrids were superior to the parents for these traits and heterotic effects were in the desired direction.

\section{References}

Alam, M. F., Kumar, M. R., Nuruzzaman, M., Parvez, S., Swaraj, A. M., Alam, I. and Ahsan, N. 2004. Genetic basis of heterosis and inbreeding depression in 
rice (Oryza sativa L.) J. Zhejiang University Sci., 5 (4): 406-411.

Annadhurai, A., and Nadarajan, N. 2005. Heterosis for yield and its component traits in rice. Madras Agri. J., 88(1-3): 184-186.

Barr, H. D. and Weatherley, P. E. (1962).A re-examination of the relative turgidity technique for estimating water deficit in leaves.Australian Journal of Biological Science.15:413-428.

Bhandarkar, S., Rastogi, N. K. and Arvind, K. 2005. Study of heterosis in rice. Oryza, 42 (3): 218-119.

Datt, S., and Mani, S. C. 2004. Heterosis for yield and grain dimensions in basmati rice (Oryza sativa L.). Oryza, 41(1 and 2): 4-7.

Dwivedi, D. K., and Pandey, M. P. 2012. Gene Action and Heterosis for Yield and Associated Traits in Indica and Tropical Japonica Crosses of Rice (Oryza sativa L.) Involving Wide Compatibility Gene(s). International Journal of Plant Breeding and Genetics 6: 140-150.

Eradasappa, E., Ganapathy, K. N., Satish, R. G., Santhala, J. And Nandarajan, N. 2007. Heterosis studied for yield and yield components using CMS lines in rice. Crop Res., 34 (1, 2 and 3): 152155.

Gupta, S.K. (2000). Plant Breeding: theory and techniques. Published by updesh purohit for Agrobios, India.

Hong, D.L., K.Q. Yang, and E.F. Pan 2002. Heterosis of F1s derived from different ecological types and combining ability of their parents in Japonica rice (Oryza sativa L.). Chinese J. Rice Sci., 16(3):216:220.

Janaradhanam, V., Nadarajan, N. and Jebraj, S. 2001. Studies on heterosis in rice (Oryza sativa L.). Madra Agric. J., 88: 721-723.

Kumar, A., Singh, S., and Singh, S, P. 2012.
Heterosis for Yield and Yield Components in Basmati Rice. Asian Journal of Agricultural Research 6(1): 21-29.

Kumar, S., Singh, H. B., Sharma, J. K. and Sood, S. 2010. Heterosis for morphophysiologicsl and qualitative traits in rice. Oryza, 47 (1): 17-21.

Li, W., J.Z. Zhang, G.Q. Zhang, and Q.F. Zuo 2002. Analysis of heterosis of main agronomic traits in Indica-Japonica lines of rice. J. southwest Agric. Univ., 24 (4): 317-320.

Lokaprakash, R., Shivasankar, G., Mahadrppa, M., Gowda, B. T. S. and Kulkarni, R. S. 1992. Heterosis in rice, Oryza, 29: 293-297.

Malini, N., Sundaram, T., Ramakrishnan, S. and Saravanan, S. 2006. Prediction of hybrid vigour for yield attributes among synthesized hybrids in rice. Research Journal of Agricultural and Biological Sciences 2: 166-170.

Manickavelu, A., N. Nadrajan, S.K. Ganesh and R.P. Gnanamalar 2006. Genetic analysis of biparental in rice (Oryza sativa L.). Asian J. Pl. Sci., 5(1): 33-36.

Najeeb, S., Zargar, M. A., Rather, A. G., Sheikh, F. A., Ahanger, M. A. and Razvi, S. M. 2011. Combining ability study in rice (Oryza sativa L.) under temperate conditions of Kashmir. Electronic Journal of Plant Breeding 2(1): 31-40.

Neelam, S., Ramesha, M. S., Reddy, T. D. and Sankar, A. 2009. Study of heterosis by utilizing male sterility-restoration system in rice (Oryza sativa L.). Journal of Rice Research 2: 110-120.

Nuruzzaman, M., M.F. Alam, M.G. Ahmad, A.M. Shohael, M.K. Biswas, M.R. Amin, and M.M. Hossain 2002. Studies on parental variability and heterosis in rice. Pakistan J. Biol. Sci., 5(10): 10061009.

Pandya, R., and Tripathi, R. S. 2006. 
Heterosis breeding in hybrid rice. Oryza, 43 (2): 87-93.

Parihar, A., and Pathak, A. R. 2008. Heterosis for various quantitative traits in rice. Oryza 15: 181-187.

Patil, D. V., Thiyagarajan, K. and Pushpa, K. 2003. Heterosis exploration in two line hybrid rice (Oryza sativa L.). Crop Research, 25: (3) 514-519.

Ram, S.G., V. Thiruvengadam and K.K. Vinod 2007. Genetic diversity among cultivars, landraces and wild relatives of rice as revealed by microsatellite markers. J. Appl. Genet. 48(4): 337-345.

Rao, A. M., Ramesh, S., Kulkarni, R. S., Savithramma, D. L. And Madhusudhan, K. 1996. Heterosis and combining ability in rice. Crop Improvement, 23 (1): 53-56.

Rashid, M., cheema, A. A. and Ashraf, M. 2007. Line $\mathrm{x}$ tester analysis in basmati rice. Nuclear Institute for Agriculture and Biology (NIAB) P. O. Box 128, Jhang Road, Faisalabad,Pakistan Pak. J. Bot., 39(6): 2035-2042

Roy, S. K., Senapati, B. K., Mahapatra, S. P. and Sarkar, K. K. 2009. Heterosis for yield and quality traits in rice. Oryza, 46 (2): 87-93.

Singh, N. K., Singh, A. K., Sharma, C. L.,
Singh, P. K. And Singh, O. N. 2007. Study of heterosis in rice using line $\mathrm{x}$ tester mating system. Oryza, 44 (3): 260-263.

Srivastava, H. K., 2000. Nuclear control and mitochondrial transcript processing with Relevance to cytoplasmic male sterility in higher plants. Crop. Sci., 79(2): 176 186.

Tiwari, D. K., Pandey, P., Giri, S. P. and Dwivedi, J. L. 2011. Heterosis studies for yield and its components in rice hybrids using CMS system. International Journal of Botany 10: 2942.

Venkatesan, M., Anbuselvam, Y., Murugan, S. and Palaniraja, K. 2008. Heterosis for yield, its components and grain traits in rice (Oryza sativa L.). Oryza, 45 (1): 76-78.

Yadav, L. S., Maurya, D. M., Giri, S. P. and Singh, S. B. 2004. Nature and magnitude of heterosis for growth yield and yield components in hybrid rice. Oryza, 41 (1 \& 2): 1-3.

Yuan, S., S. Wen, Z. Li, J. Wan, Y. Tian and C. Liu 2000. Study on the combining ability of indica two line hybrid rice. $J$. huazhong Agric. Univ., 19: 204-208.

\section{How to cite this article:}

Santosh Kumar, N.K. Singh, Rajesh Kumar, Satish Kumar Singh, Nilanjaya, Chandan Kumar and Avinash Kumar. 2017. Heterosis Studies for Various Morphological Traits of Rice under Drought Conditions. Int.J.Curr.Microbiol.App.Sci. 6(10): 507-521. doi: https://doi.org/10.20546/ijcmas.2017.610.062 